Forests 2011, 2, 525-549; doi:10.3390/f2020525

OPEN ACCESS

forests

ISSN 1999-4907

www.mdpi.com/journal/forests

Article

\title{
REDD+ and the Indigenous Question: A Case Study from Ecuador
}

\section{Pablo Reed}

Yale School of Forestry and Environmental Studies, 195 Prospect Street, New Haven, CT 06511, USA; E-Mail: pablo.reed@yale.edu; Tel.: +1-203-824-7733; Fax: +1-203-436-9135

Received: 3 March 2011; in revised form: 12 April 2011 / Accepted: 13 April 2011 /

Published: 13 April 2011

\begin{abstract}
One of the main issues regarding the implementation of REDD+ in Latin America has been the growing concern that such projects may infringe upon the rights and negatively affect the livelihoods of forest-dependent communities. Various indigenous and civil society organizations are ardently opposed to the initiative. Such is the case in Ecuador, where indigenous opposition to REDD+ represents a considerable obstacle in the creation of a national strategy since more than $60 \%$ of the country's remaining forest cover is on indigenous land or under indigenous occupation. Thus one of the most critical challenges remaining for Ecuador will be the construction of a strong legal, financial, and institutional framework — one that the greater indigenous community might be willing to accept. Closer examination of this topic however, reveals just how difficult this may become. Lack of information, a recent political split between national authorities and the indigenous sector, and the dissimilar organizational capacity levels of indigenous communities make the feasibility of carrying out REDD+ projects on these lands extremely complex. However, the biggest obstacle may be ideological. Many indigenous groups view REDD+, with its possible emphasis on international markets and neoliberal mechanisms, as a continuation of the type of policies that have impeded their quest for sovereignty and self determination. As such, indigenous people are only willing to consider such projects if they clearly see preconditions in place that would safeguard their cultures, territories, and autonomy.
\end{abstract}

Keywords: REDD+; indigenous; ecuador; communities; rights; socio-bosque; forests 


\section{Introduction}

One of the most notable successes of the United Nations Climate Change Conference held in Cancun this past December was a general agreement on Reducing Emissions from Deforestation and Forest Degradation, the enhancement of forest carbon stocks, and the conservation and sustainable management of forests in developing countries (REDD+). Despite considerable remaining uncertainties regarding the general framework of such project schemes, the agreement is expected to revitalize and increase funding flows to support REDD+ readiness efforts worldwide [1]. Various countries have commenced the crafting of national strategies and a number of them have begun to launch pilot projects in their quest to obtain some of this pledged financial support [1]. The small South American nation of Ecuador is included in this group as it seeks to enter the United Nations REDD program in 2013 [2]. Under existing economic and social conditions, the country faces many of the obstacles characteristic of poor nations hoping to join the program: weak forest-sector governance, corruption, increasing population pressures, and a plethora of disputed property rights. Yet it has also become a prime example of one of the other main issues of concern regarding REDD+ implementation; that of such initiatives infringing upon and negatively affecting the rights and livelihoods of forest dependent communities.

Analogous to what has transpired at the global level, various national indigenous and civil society organizations have and continue to be ardently opposed to REDD+ [3-6]. With more than $60 \%$ of the country's remaining forest cover under indigenous land or occupation [7], it could not be more clear that one of the most critical and difficult challenges remaining for Ecuador to become a viable "REDD" country [8] will be the construction of a strong legal, financial, and institutional framework - one that the greater indigenous community might be willing to accept. Closer examination of this topic however, reveals just how difficult and time consuming prevailing over such an obstacle might become.

The topic of REDD+ has surfaced at a very particular time in Ecuadorian indigenous and environmental politics. For one, the country has only recently ratified a new constitution, which leaves undone many of the necessary laws and norms needed to adequately establish carbon rights or ownership and, more generally, to guide any type of payments for environmental services [3,9]. Despite a collaborative effort between Rafael Correa's government and the indigenous sector in the drafting of this new piece of legislation, these two groups are now at odds over how to interpret its articles and on what roles nature and the environment should play in the greater development of the nation. Such a political split has sometimes made both opposition and progress on REDD+ more a question of politics than any technical or implementing concern.

However, indigenous opposition to REDD+ goes beyond this political divide. The disapproving rhetoric coming from the indigenous sector in Ecuador is undoubtedly also linked to the greater fears and concerns indigenous people and observers have expressed worldwide [10-12]. Indigenous groups have long considered themselves to be the principal victims of capitalist, neoliberal, and market policies. Through much of their recent history, these policies have brought an onslaught of global and extractive economy measures directly to their doorstep, often resulting in ghastly negative environmental consequences for their territories and livelihoods [13,14]. Hence, many players view REDD+, with its possible emphasis on international markets and neoliberal mechanisms, not only as a 
continuation of the type of policies that have impeded the arduous quest for sovereignty of indigenous peoples, but even as one of the root causes for deforestation and climate change.

Such notions have been clearly echoed by indigenous federation leaders within Ecuador [6], yet very little attention has been given to what is being expressed at the individual tribal-nation, village, or base community levels. What is more, several indigenous communities have already signed on to a government pre-REDD+ program dubbed Socio-Bosque, suggesting that perhaps the indigenous stance on REDD+ is by no means monolithic. Perhaps some indigenous communities are beginning to perceive they have something to gain from REDD+. While this may be the case, the diversity and dissimilar organizational capacity levels (in the Western sense) of indigenous groups present yet another hurdle to overcome. Many of them have not had the sufficient time and/or contact with modern society to create new and viable political approaches for self-representation. Even those groups who have been able to systematize their efforts enough to consolidate rights to their territories and devise practices to protect them may not be ready for REDD+.

In any case, it must be recognized that indigenous communities are once more being asked to buy into an idea handed to them "from above". By doing so, many of them would enter a realm of modern, global, and western society that values their forests for different reasons than their own. Tensions stemming from dissimilar social and cultural notions of how humankind should interact with its environment will be inevitable. This time, however, indigenous groups seem well intent on entering and preparing to engage in such projects, if and only if, they clearly see preconditions in place that would safeguard their cultures, territories, and autonomy [3,4,14-16].

This study thus seeks to use the Ecuadorian example as a means to bring forth some of the most critical issues and obstacles concerning the inclusion of indigenous territories under national REDD+ strategies in Latin America. It begins by providing a general background on deforestation within the country, as well as an examination of how the rise of a strong indigenous movement has allowed for it to become a considerable force within matters of national politics and environmental policy. It then deconstructs the recent political split between the national government and the indigenous sector, and shows how a global, unified, indigenous discourse on REDD+ has influenced opposition at the national stage. This is then followed by an analysis of three different case studies which illustrate the specific concerns and predicaments of indigenous groups at the tribal-nation and community levels. Finally, the study ends with a summary of the key points discussed, lessons taken from them, as well as observations and recommendations to possible paths of reconciliation to include indigenous territories under a national REDD+ framework.

\section{Research Methods}

To explore this topic fully, research has been conducted over the course of twelve months. Preliminary data were first gathered to examine deforestation as well as the emergence of a strong indigenous movement within Ecuador. The rise to power of Rafael Correa, the collaborative effort between his administration and the indigenous movement in the drafting of the new constitution, as well as the political divide that has surfaced between these two groups in recent months, were also investigated. This was done through the use of academic literature reviews, analysis of national and international media outputs, as well as periodic and personal informant interviews. 
Similar methods were also employed to track the development of REDD+ strategies and policy approaches at international climate change negotiations and other forums. This included the review of both academic and project literatures, as well as those stemming from civil society observer and human rights based organizations. Global indigenous participation at international environmental deliberations, as well as these groups' concerns and reservations with regards to REDD+, were also examined. Finally, all these preliminary data were then complemented by a period of qualitative research within Ecuador from June to August 2010 to obtain primary data from indigenous participants and other pertinent stakeholders.

Primary data during this period were gathered through the use of key informant, open ended interviews, focus groups, and participant observation with various members of the 14 indigenous tribal-nations within Ecuador. The three main participant tribal-nations were chosen based upon their availability and willingness to take part in the study, as well as on their perceived stance on the topic of REDD+. Using the government's Socio-Bosque program as a case study, one tribal-nation was chosen based on their participation with the program for over a year, another on their recently expressed interest in joining, and the last on their expressed opposition to or little interest in the project. These tribal nations were the Cofan, Waorani, and Awa communities of Ecuador, respectively. Spokespersons and delegates were interviewed from each of these tribal-nations' main representative institutions; FEINCE (Federacion Indigena de la Nacionalidad Cofan del Ecuador) in the case of the Cofan, NAWE (Nacionalidad Waorani del Ecuador) in the case of the Waorani, and FCAE (Federacion de Centros Awa del Ecuador) in the case of the Awa. With the permission and guidance of NAWE, interviews were also conducted with Waorani villagers in the communities of Guiyero and Timpoca located within the Yasuni National Park, as well as with a team of Waorani GPS technicians and NAWE employees. Through participant observation and interviews conducted at regional climate change, REDD+, and Socio-Bosque information conferences, perspectives on the topic were also gathered from representatives and villagers from three additional indigenous tribal-nations, the Shuar, Chachi, and Amazon Quichua. This data was then also accompanied with documentation and interviews gathered from various international and national NGO's, civil society organizations, indigenous federation representatives, and government environmental officials. All of the interviews conducted were approximately 30 minutes to an hour in length and the data gathered consisted mostly on perspectives and viewpoints on REDD+ and Socio-Bosque, with some relevant social, political, and economic information also included. In various cases, participants wished to remain anonymous in order to protect their privacy.

\section{Ecuador and its Forests}

The Republic of Ecuador straddles the equator in the northwestern portion of the South American continent, sharing its borders with Colombia in the north, Peru in the south and east, and the Pacific Ocean in the west. The country is subdivided politically into 24 provinces distributed over four distinctive geographic areas; the Galapagos islands, the coastal region, the 'sierra' or mountainous region, and the Amazon basin or 'oriente' region. Despite its relatively small size (255,234 square $\mathrm{km} \mathrm{[17]),} \mathrm{the} \mathrm{country} \mathrm{is} \mathrm{home} \mathrm{to} \mathrm{an} \mathrm{impressive} \mathrm{array} \mathrm{of} \mathrm{both} \mathrm{biological} \mathrm{and} \mathrm{human}$ diversity. Considered one of the planet's 17 mega-diverse countries by Conservation International [18] 
it is said to hold $18 \%$ of the world's bird species, $10 \%$ of its vascular plants, $8 \%$ of its mammal species and $10 \%$ of its amphibious species [19]. Its roughly 14 and a half million people are composed of a mix of Mestizo (65\%) and Amerindian (25\%) populations, of which there are 14 formally recognized ethnicities. The rest is made up of a small portion of white Spanish (7\%) and African descendent (3\%) communities [20].

Natural resource extraction has always been the base upon which the social and economic development of the country has been supported [21]. The Ecuadorian economy has long been categorized as a supplier of raw materials and as such, has shown much of the same dynamism of cyclical booms in global market commodities [cacao (1866-1925), bananas (1946-1968), and oil (1972-2010)] [21]. In the period stretching from 1990 to 2009, only $22 \%$ of its total exports were of an industrialized or value-added nature, with the remaining $78 \%$ still mainly consisting of raw materials or primary products, such as oil, bananas, cacao, shrimp, and flowers [22]. Much of the benefits of this extractive economy have gone directly to the hands of the country's elite, allowing for a highly disproportionate distribution of wealth as well as imbalanced social and economic development. As of today, statistics show that $61.3 \%$ of the population lives in poverty and that almost half of this percentage does so in the extreme nature, where most of the basic needs for survival have still not been adequately met [20].

A primary victim of the extractive economy has been the nation's forests. Ecuador has been labeled a country with a high forest cover and a high deforestation rate [23]. The most recent calculated rate of deforestation was done in the year 2000, when estimates put the loss of forest cover at an alarming rate of $1.47 \%$ or 198,000 hectares being lost per year, marking it as one of the highest in all of Latin America [24]. Deforestation in Ecuador has run rampant ever since the passing of agrarian reform laws in 1964 and 1972 which promoted the colonization of 'vacant' forest land as the solution to social pressures caused by an inequitable, feudal land distribution [25]. In a strong push to exploit these newly opened up areas, colonists from across the country and under the auspices of government sponsored programs proceeded to log and clear forests to set up massive agro-industrial monocultures, the most notable of which have been banana, cacao, coffee, and African oil palm. These drives for agro-industry were later coupled with modern global enterprises seeking to exploit the vast reserves of oil and precious minerals that were identified underneath these lands. With a growing population and a higher demand for land, the 10 million hectares of forest that remain in the Amazon basin and on the country's northwestern coast are now also under attack [19]. The only comparatively good news in this respect is that about $37 \%$ of the forest that remains is in the eastern Amazon 'oriente', still considered frontier land, and as such, still relatively inaccessible by most means of transportation [19].

Modern Ecuadorian governments, trying to conserve what remains of the country's forest cover, have created a number of protected areas and conservation zones, which now cover approximately $26 \%$ of the Ecuadorian territory [26]. Despite these efforts, policies and programs have failed to effectively protect and, in some cases, have constituted a direct menace to conservation efforts in these areas. Oil, mining, and road-building activities continue unabated inside protected areas. Contradictory laws, policies, and lack of coordination between different government ministries continue to hamper the development of a coherent national conservation strategy. Protected area projects in Ecuador remain chronically underfunded and continue to be plagued by administrative inefficiencies and an absence of participatory strategies that would include local populations [5,9,14,27]. 
Incessant political and economic instability also has exacerbated the situation. The country has survived nine presidents over the past 15 years and has been beset by several significant financial crises. The biggest one of these came in 1999, which pushed authorities into a policy to adopt the US dollar as its official currency when its original 'Sucre' suffered a devaluation of $65 \%$ in a span of just a few years [21]. Today, Ecuador remains a nation characterized by deep social and economic inequality. The lack of economic alternatives for vast portions of the population, coupled with poor governance, continuous pushes for agro-industry and livestock, and numerous problems with disputed property rights, only further the compulsion to clear more forested land. The forests that remain do so largely in the hands of indigenous communities. Having lived amongst these forests for millennia, they consider these lands as an intrinsic part of their identity and well-being, and have guarded them as such; though their struggle hasn't been an easy or straightforward one by any stretch of the imagination.

\section{The Rise of a Strong Indigenous Movement}

Life for the indigenous in Ecuador has not been easy. They have long been the most socially and economically marginalized sector of society, suffering from cases of discrimination, high levels of poverty, low levels of education, and inadequate access to basic health services [28]. Within the last thirty years however, the country has been witness to the rise of what some have labeled as one of the most active indigenous movements in the Americas [29], making this once disenfranchised group a now powerful political force with considerable influence over matters of political, environmental, and developmental policy.

The rise of such a movement is said to have begun in the 1920s, when indigenous activists first started organizing themselves against the state's exclusionary policies by making key alliances with leftist urban groups and other groups of landless peasants [30]. Inspired by the events of the Cuban revolution, and enlisting the support of a rising middle class, these movements were instrumental in the struggle that forced the government to pass agrarian reform laws [29]. Building on the progress gained through this reform and using the political spaces unlocked by the country's return to Democracy in 1979, the indigenous movement slowly began to solidify itself and finally experienced mild successes in mobilizing the marginalized. The neoliberal policies that characterized the nation's governments in the 1980s, though highly exploitive themselves, allowed for even more maneuverability within the political and social vacuums left by an increasingly contracting and incompetent state. Since then, the indigenous movement in Ecuador has progressed in lock step with the population's growing discontent for government policies that favored the wealthy elite at the expense of the nation's poor, their territories, and the environment.

Building on decades of struggle, the 1990s finally saw "the transformation of indigenous movements in some Latin American countries from momentarily influential outsiders to powerful and effective collective political actors with a sustained presence in regional and national politics" [31]. This became evident in Ecuador with the creation of a national indigenous confederation Confederacion de Nacionalidades Indigenas del Ecuador (CONAIE), which brought together indigenous movements from the coastal, Andean and Amazon zones of the country under one umbrella. In June of 1990, a powerful indigenous uprising spearheaded by CONAIE paralyzed the country with 
roadblocks for seven days straight and became the largest protest by social organizations in the country's history. Protesters in this uprising called for land, economic development, education, and recognition of indigenous nationalities, marking a new era of strategies in organizing civil society in their demands for rights [30].

CONAIE, its political party, 'Pachakutic', and the larger indigenous movement, continued to play an important role in Ecuadorian politics in the years that followed the uprising. They were instrumental in the ousting of President Bucaram in 1997, helped pass collective rights for indigenous people in the modified constitution of 1998, and organized a rebellion alongside the military that deposed the presidency of Jamil Mahuad in 2000. Their support for candidates friendly to their cause was influential in the rise of power of President Gutierrez in 2002 and Rafael Correa in 2006, and their participation in the most recent constitutive assembly greatly influenced the language and stipulations of the newly ratified constitution.

Distinctive discourses and strategies employed by this movement have allowed for its success. For one, CONAIE and the larger indigenous movement were able to create a unifying, ethnicity-based, self-identification that incorporated all the heterogeneous indigenous groups that made up its ranks. In doing so, they were able to articulate a unified 'tribal slot', a strategy employed elsewhere by other indigenous groups, much like the successful campaign of the Lindu in Indonesia examined by Li [32]. This strategy was also made possible by the gradual construction of networks that linked local communities from around the country with regional federations, national and international indigenous organizations, and NGO's. Their unified anti-neoliberal posture was also made possible by the creation of a discourse that intimately associated ethnicity with territory, and which identified indigenous communities as caretakers of the environment. In this respect, "place and identity became sources of legitimatizing territorial claims, and were in this way intimately linked to struggles over material resources" [33].

It is irrefutable that the rise of the indigenous movement has brought political and social change to the country. Today, the indigenous people of Ecuador enjoy higher degrees of participation and representation in national politics. Ironically though, these qualities seem only to be showcased in times of crisis. Rallying against the policies of unpopular politicians, governments, and parties represented the pinnacles of success for the indigenous movement as they were able to collectively organize against what was happening at the top administrative level. However, once these politicians were replaced, and positions for the indigenous within state politics and institutions opened up, their leaders became part of the bureaucratic and inefficient political systems they once fought against. Various administrations and politicians have thus been able to co-opt and entice leaders into their particular causes, thereby deepening divisions amongst many of the once strong organizations and factions of the indigenous movement. The indigenous plea for environmental protection and territorial autonomy also suffered similar setbacks against the strategies of government environmental and developmental policies. While numerous indigenous communities now hold land titles to their ancestral lands, the state has retained the sub-surface mineral rights, making the state and not the communities the ultimate authorities in deciding whether drilling, mining and extraction permits are to be handed out. 


\section{A New Era of Ecuadorian Environmental Politics}

Continuous political tumult within the country once again allowed for the overthrow of another democratically elected president, in this case, Lucio Gutierrez, in mid 2005. Though he was the third president to be ousted in less than a decade, opposition to his rule had much more to do with his administration's nepotism, corruption and meddling in the courts, than with economic instability and social unrest [29]. Out of the ashes of this latest change in office came Rafael Correa, a U.S. and Belgian trained economist who before running for office was relatively unknown and had almost no history of working directly in Ecuadorian politics. Pledging to reject the neoliberal and oligarchic policies of his predecessors, he called for a "citizens' revolution", where one if its main platforms was to create a constituent assembly to write a new constitution to put an end to what he labeled, "the long night of neo-liberalism." [3]. His campaign remarks spurred optimism within the indigenous sector. They saw this as an opportunity to press for additional social, economic, territorial and environmental issues. The result was their full-fledged support for his candidacy, which ultimately helped him in part to win the presidency in 2006, organize a constituent assembly in 2007 , and shortly thereafter ratify a new constitution [34].

This new constitution of Ecuador has been revered as the world's first eco-constitution [35], and the indigenous sector proved to be one of its most influential groups in its creation. The conditions, concepts, and stipulations set forth by its articles set it apart from others by recognizing inalienable rights to nature. What is more, it specifically refers to nature by the indigenous term Pachamama, or mother Earth, and provides a new context in which it lays out the framework for political and environmental management stipulations based on the indigenous notion of sumak kawsay, or the good life. Such notions represent a huge victory for indigenous people, given their desire for the newly-framed constitution to break ties with prevailing influences and sanction their more traditional knowledge and expertise with regards to matters of the environment.

But the day the final text of the new constitution was to be promulgated also marked the beginning of a schism between Correa's administration and the indigenous faction. In his speech at the ceremony, Correa declared that the "principle dangers" to his citizens' revolution did not stem from far-right opposition but from "extreme leftism and infantile environmentalism and indigenaism" [36]. The man who had reached the presidency largely owing to their support, who often opted to wear a white shirt with embroidered indigenous symbols rather than a suit and tie to public events, emerged as a new public foe of the larger indigenous movement. Besides establishing progressive environmental measures, the new constitution vastly increased the power of the executive branch, and a number of clauses within its articles contained strategic exceptions whereby certain natural resources would now be considered key strategic resources of the state. Of particular interest for the REDD+ debate are articles 261 and 74 of the new constitution, which assert that the state will maintain exclusive authority over forest resources and that environmental services could not be subject to appropriation and would therefore be regulated only by the state [37]. As Correa began to layout out his national development plan, it became clear to the indigenous community that, at least for the time being, his administration showed no intent of halting the exploitation of natural resources within indigenous territories for the sake of further 'developing' the nation [34]. 
The indigenous community felt betrayed. In the months that have followed the constitution's ratification, government pushes for the creation of new laws under its auspices have been sources of conflict between the indigenous movement and Correa's administration. Campaigns for the passing of a new Food Sovereignty Law, a new Environmental Code, a new National Security Law and a National Development Plan, have all been met with indigenous opposition [34]. What's more, this opposition has now also moved beyond the boundaries of the indigenous communities to include several environmental and humanitarian organizations, the most outspoken of which have been two NGO's named Pachamama and Accion Ecologica. This new opposition group has declared that these decrees violate the new constitution and once again threaten the rights and critical environmental protection of indigenous lands [5]. Countering this, the president's administration argues instead that the constitution will be used to enforce state regulation of oil and mining enterprises, ensuring these entities would have to pay larger taxes, respects its local workers, and adhere to social and ecological responsibility guidelines [2]. The opposition is not "buying" such arguments, and confrontations have steadily escalated in numbers and intensity, even to the point of violence.

Spearheaded by the indigenous movement, the opposition began organizing and building grassroots level support against the aforementioned Environmental Code ever since it was first proposed by the administration. They claimed that this new code contradicts the principles of sumac kausay by placing indigenous communities near or within declared conservation areas under the National System of Protected Areas (SNAP), to be managed by the state rather than by the communities themselves. The proposed code also classifies water and the carbon stored in forests as environmental "services" whose only holders can be the state. The indigenous concern in this respect is that water reserves and forests could thus become subject to commercial agreements with entities and corporations outside of communities' jurisdictions [3]. On September 30th, 2009, indigenous protesters demonstrating against the proposed code violently clashed with police forces in the southern Amazon city of Macas, resulting in the death of an indigenous school teacher and leaving more than 30 protesters and police wounded [38]. The incident represented the pinnacle of tensions that had been brewing between the government and the indigenous sector for months. As a result, deliberations for approving the environmental code were postponed indefinitely.

Such a political crisis could not have come at a worse time for the prospects of REDD+ within Ecuador. Tensions after this violent confrontation have not subsided and have made dialogue between national indigenous leaders and government officials close to impossible. These developments occurred at a time when the Ecuadorian government, having been actively participating in REDD+ deliberations at international negotiations, was finally preparing to construct a coherent national strategy. Plans had been made to put together a consultation process in order to construct a legal framework under which carbon rights and ownership could be regulated and payments for environmental services could be implemented under the new constitution [2]. What is more, the government had also launched a pre-REDD+ initiative called Socio-Bosque with the help of Conservation International, which had already managed to sign up several indigenous communities.

Under this program, the government provides an annual economic incentive per hectare of forest to individuals or indigenous communities who voluntarily decide to protect the native forest they own. In order to join the program, landowners are required to submit documentation to the Ministry of the Environment, including a copy of their land title along with the proper zoning and coordinates of the 
land they wish to incorporate [2]. Once this documentation is confirmed by the ministry and verification of the same is carried out in the field, landowners then sign a contract for 20 years followed by a period of indefinite renewal [2]. In the case of communities, the contract must include an investment plan showing how the community will decide to invest the resources provided by the program [2].

Only launched in the latter half of 2008, the Socio-Bosque program is still in its infancy and therefore, still has to overcome many limitations. The long-term financial solvency of the program remains in question, and the need for better coordination between its office and different government ministries and agencies is apparent. Furthermore, the amount of $\$ 30$ offered per hectare of forest conserved is still considered relatively low in comparison to the returns from other potential land uses [39]; and under its current policy, this amount begins to taper off when the amount of land inscribed in the program exceeds 50 hectares [2]. However, the program offered a simple enough avenue for many indigenous communities to perceive it as a way to reap profit from an activity they have been striving for this entire time, the protection of their forests. Numerous indigenous communities had already signed up to the program, with few, if any, complications [2,16]. However, the political tension that has surfaced has now caused the indigenous movement to reject any proposals coming out of Correa's administration, even if they appear beneficial to their environments or to their economic plight. Such political obstacles add to the fears of forest dependent communities that have surfaced worldwide with the proliferation of REDD+. It is these worries which have now also been adopted by the indigenous movement within Ecuador.

\section{The Echoing of a Global Discourse}

Besides the relevant national political dynamics, the indigenous opposition to REDD+ in Ecuador has also been a product of what has transpired in the global arena. Climate change negotiations, and the REDD+ debate in particular; have opened up significant political spaces and platforms for indigenous organizations worldwide in their struggle for recognition of their sovereignty, self determination, and traditional land rights.

One of the primary arguments from indigenous people has been a straightforward call for inclusion. These groups have been adamant in criticizing their lack of participation in the UNFCCC process. Feeling shunned by representatives of their own national governments, they organized their own International Indigenous Peoples Forum on Climate Change (IIPFCC) in 2000. Similar sentiments were expressed at the negotiations of REDD+ in Bali, where they felt they were generally excluded from the creation of an initiative that will have immediate and significant consequences for millions of people who depend on forests for their livelihoods [11].

These notions have formulated a solid ideological foundation from which the indigenous groups have criticized REDD+, labeling it as a 'false' solution to climate change. A significant element here lies in the indigenous notion that it has been developed countries' greed and unrelenting and uncontrolled consumerism which have bled the planet of its natural resources and hurt its atmosphere; and that REDD+ and its ideals simply constitute another ploy to perpetuate the tendencies of industrialized nations to ignore their own responsibility to reduce their own emissions $[6,11,12,40]$. 
This rhetoric is echoed in Ecuador as is evidenced by the following statement given by Marlon Santi, the current president of CONAIE, at a recent indigenous climate change conference held in Bolivia:

"REDD+ is not a solution to climate change........[it] has been created by multilateral institutions like the World Bank that routinely violate Indigenous Peoples' rights and pollute Mother Earth. It is perverse that these institutions are pretending to have the 'solution' when they have actually caused the climate crisis. REDD+ should not be implemented in any country or community."

Marlon Santi [12]

The other widespread concern for indigenous peoples is that REDD+ may jeopardize their rights to their territories, sovereignty, and self determination. Such concerns go beyond the indigenous sector and have been echoed by various academics and rights-based organizations world-wide [10,11,41]. These observers criticize the quick proliferation of REDD+ projects which still ignore the rights, tenure, and engagement of indigenous communities [42,43] and may even encourage displacement, conflict, corruption, impoverishment, and cultural degradation [10]. Moreover, the fact remains that a considerable portion of indigenous peoples' customary lands lack demarcation and titling. Coupled with imprecise definitions of what may constitute a "forest" or "degradation", indigenous people fear their lands may be replaced by tree plantations or monocultures that increase carbon stocks at the expense of their ecosystem's integrity, biodiversity, and socio-cultural value [10].

These concerns and fears are not unsubstantiated. Instances of displacement and coercion of native communities have already been documented in Uganda, while civil society observers in Indonesia have expressed their concern that the state may soon move to expropriate community forests and impose involuntary resource use restrictions on local populations as part of their REDD+ readiness program [10]. Such risks may even also stem beyond the actions of the state. REDD+ has brought with it a proliferation of would-be brokers, some legitimate, others not, looking to capitalize on the vast amounts of new money that will be made available. These would-be brokers are moving quickly in their quest to gobble up land and carbon rights. Ecuadorian indigenous community members all mention how at some point they have been subject to such ploys by "ghost" NGO's and other dubious organizations $[4,14,16]$. Without the appropriate information in hand, indigenous communities could also fall victim to unfavorable agreements with dubious organizations seeking involvement in REDD+, perhaps further jeopardizing rights to their territories.

One of the most notable cases and examples in this respect was when an American company named Eco-Genesis signed a usufruct agreement with NAWE, the political organization of the Waorani Indians of the eastern Ecuadorian Amazon, in 2005. The stipulations of the agreement granted the usufruct rights to two considerable pieces of Waorani land to the company, allowing it to commercialize the environmental services from this rainforest (specifically, $\mathrm{CO}_{2}$ credits) to the international market, with the Waorani renouncing any claim for a period of 30 years [14]. After the contract was made public, it became clear that the vast majority of the Waorani community had never been consulted or even notified of such an agreement. A Waorani assembly convened shortly thereafter to reject the agreement and to fire NAWE's president, whom they accused of corruption and collusion with the foreign company. Cases like this ultimately led to the aforementioned article 74 of the new constitution, in order to prevent such instances from occurring in the future. 
Indigenous groups now suspect that there are similar dangers when schemes are managed and directed by national government authorities. Fair and reasonable distribution of benefits are of high concern, and will be pivotal to REDD+'s acceptance. Observers also note that the use of national baselines to gauge the effectiveness of REDD+ threatens to recentralize forest governance once more [44] and that the valorization of natural resources from the outside often means that "external political and economic forces will become involved, and the less likely is it that local inhabitants will be able to retain control" [45].

In any case, Hirtz's notion that it takes modern means to be indigenous [46] has proven true. Indigenous groups have been exceptionally successful in organizing themselves. These efforts, which have even included internet and mass media campaigns, paid off in 2007 when the United Nations General Assembly adopted the UN Declaration on the Rights of Indigenous Peoples (UNDRIP). Such a step was heralded as a huge victory for these groups in gaining political leverage in their struggles for rights and self determination. But the impact of such victories remains unclear. It is still uncertain how effective the declaration will be in defining and safeguarding these groups' rights. Important principles in the declaration itself, such as the right to self-determination and, free, prior, and informed consent, are still open to wildly different interpretations. Formal legal frameworks for their implementation remain to be created in Ecuador and much of the developing world. Nevertheless, such strides are important as they appear to present indigenous groups with new alternatives with which to defend their interests. Recognition of the UNDRIP and other safeguards were included in an addendum to the REDD+ agreement reached in Cancun. Though such a step has been heralded as an important one by many indigenous observers, others still consider REDD+ as a potential threat, especially if a market system to fund such projects is considered in the future [40].

\section{Gaps in Information}

Within Ecuador, as mentioned earlier, the once strong indigenous organizations, such as CONAIE, have steadily weakened in the decades that have followed the 1990 uprising due to the cooptation of its leaders by government and special interests. This has led to deepening divisions within communities, and perhaps most importantly, to a growing disconnect between the concerns and demands at the community level and the actions of top level indigenous leaders. Today, numerous indigenous communities no longer consider CONAIE to be an institution that can truly represent their interests and speak on their behalf [14].

As a result, the indigenous stand on REDD+ in Ecuador is by no means monolithic. Proof of this is evident by the numbers of communities that have signed on to the government's Socio-Bosque program despite CONAIE's rejection of it. However, most of the country's indigenous populations are indifferent, or to a certain extent distrustful of REDD+, in part because they have never heard of it. While the Ecuadorian government has created a comprehensive international public relations campaign praising it's REDD+ readiness efforts and Socio-Bosque program $[47,48]$ very little has been done to promote REDD+ within Ecuador, much less within the indigenous sector and its base communities.

At the village level, while some participants admit to having heard something about Socio-Bosque and the basic structure of what this program entails, almost none have heard of REDD+, much less about notions of carbon emissions or the green-house gas effect. This isn't to say that the idea of 
climate change is completely foreign to them. If anything, climate change is a popular topic, and one of growing concern. Numerous villagers speak of considerable changes they have witnessed in their weather regimes. Variations in rainfall and water cycles, as well as prolonged and uncommon periods of heat, drought, and severe climatic events are seen as common throughout the country $[15,49,50]$. These changes in the environment are seen as beginning to affect their agricultural output and other subsistence activities.

What is entirely new to indigenous communities however, is this newfound interest by outsiders in their territories, and in particular, their trees. While many of them are well versed in conservation and the efforts of numerous organizations trying to work with them on this topic, the notion that now somebody wants to come in and pay them directly to preserve their forests raises a few eyebrows. By and large, their reaction to this is: "Well, what's the catch?" No one has ever attempted these types of incentive-based projects on such a large scale before, which leads to suspicion on the part of the indigenous communities. More than anything, these communities feel that there has to be some type of 'strings attached' to these projects; that there has to be some type of larger hidden or 'camouflaged' interest on the part of authorities to push so emphatically for these initiatives on their lands [4].

Particular indigenous communities' stances on REDD+ are thus highly dependent on whom and what type of information get to them first. On the one hand there is the government campaign to reach them. The intent here is to present REDD+ as an opportunity for the indigenes to profit by continuing to preserve the forest - just as they have for centuries. On the other hand, there is CONAIE and the opposition NGO's, exemplified in this respect by Accion Ecologica, which have already decided to denounce REDD+ and have closely associated Socio-Bosque with it, despite obvious and considerable differences between the two. They present these projects as a way to concede 'pollution rights' to businesses and utility markets in the developing world, and they concentrate on the perceived dangers and negative experiences such projects might bring. The two stances reflect an inherent lack of unbiased sources of information on the topic. Other institutions that could be described as being in the middle of these two stances are few and far between, have only limited resources in comparison to their competitors, and are unable to reach most of the indigenous sectors in the country.

Complicating things further is the reality that transmitting information on REDD+ to indigenous communities is difficult as they are so dispersed, many are unreachable by normal means of transportation. Government authorities, CONAIE, and the various NGO's working on the topic, admit that they lack the capacity and funding to be able to reach out to most communities. Therefore, information on REDD+ is, by and large, distributed by organizing regional conferences where only a select number of villagers from each ethnic group are allowed to attend. This compounds the problem by making only middle-aged men, and those who can afford to leave behind their daily obligations for a day or two, the only recipients of such information. Important sectors of the indigenous community, such as women and the elderly, are often left behind. Furthermore, the community members who do attend conferences make it clear that the information received on climate change and REDD+ is highly technical and difficult to understand [50]. As such, retransmitting credible, impartial, and timely information to the rest of their communities is very difficult for them, if not nearly impossible.

It seems highly unlikely that any one institution can provide complete, timely, and unbiased information on the topic of REDD+ to indigenous communities. But, at the very least, there is the recognition that these efforts should be improved upon, perhaps through different mediums. Younger 
generations, more accustomed to the ways of modern/western civilization, are especially cognizant of this. They state that their mission is to gather as much information on the topic as possible to take back to their communities so that they in turn can decide for themselves whether or not REDD+ and/or Socio-Bosque might be an option for them [14]. Probably mindful of past experiences, they are adamant on securing information from a variety of sources so as to not be steered into narrow points of view. By their own admittance, they understand that much of the data they are receiving may be biased by the larger political or funding goals of the people bringing them the information [14].

\section{Organizational Capacities and a Different Set of Priorities}

Some have argued that the opportunities for REDD+ may be strongest when pursued within indigenous territories. Pimpert and Pretty [51] point out how, within formally declared indigenous lands, local institutions typically govern the use and distribution of forest resources, ensure security of tenure, and provide a mechanism for enforcement and conflict resolution through cultural sanctions. Many of these communities would thus seem to have the necessary clarified tenure rights, built-in resource management, and benefit distribution mechanisms that are needed for the objectives of REDD+. But, herein lays a conundrum. Such communities are caught in what could be described as a 'catch-22' [52] situation. Having effectively organized themselves, many have been able to limit deforestation within their lands, much like other communities within Ecuador and elsewhere in the region [53-55]. Such a condition, however, makes them the least likely candidates for REDD+ type initiatives and/or funding, given the 'additionality' requirement common to any payments for environmental services schemes, along with the difficulty to prove how extra funding could result in a net and abrupt reduction of carbon emissions.

Additionality is the hypothesis that drives REDD+ policy makers to avoid giving credits to projects that would have happened anyway. Moreover, this concept is often posed as a question: "is the project reducing emissions in a way that is business as usual, or is it beyond business as usual?" Essentially, it is a test to see if carbon trading mechanisms are having a positive effect and are leading to measures that reduce emissions by more than that which would have occurred in the absence of the effort. It is generally understood that if investors of REDD+ want more 'bang for their buck' they should target those forests that are under the most threat. In practice, however, this carries the risk that the main winners of such project schemes could turn out to be the very ones that have been driving deforestation to begin with; such as cattle ranchers, African oil palm plantation owners, and urban developers. In turn, communities which have been conserving their forests this entire time are left out. This begs the question of how high should the additionality bars be set for REDD+? Beyond this, given that much of the enthusiasm surrounding REDD+ centers on deforestation, the 'conservation' component is often times overlooked. This reveals the urgent need to create tailored programs within national REDD+ strategies that deal specifically with the continual safeguard of conserved forests, parallel to those efforts which may deal exclusively with deforestation.

On the other hand, other indigenous groups may simply be years or decades away from effectively entering into REDD+ projects. Many of them have yet to create viable political mechanisms for self-representation and thus still lack the institutional capacity to effectively carry out these types of projects on their lands. Despite having formally recognized and collective titles to their territories, 
many individual community members still hold larger allegiances to family, clans, and in some cases to foreign institutions, rather than to unified or ethnicity-based identities. As a result, their territories are yet to be fully consolidated, leaving them vulnerable to powerful outside influences. How a national REDD+ strategy deals with these two different and difficult sets of organizational capacity levels will be paramount if it wishes to incorporate vast tracts of forest lands under its auspices.

\subsection{The Cofan}

The Cofan peoples of northern Ecuador are the descendents of a once heterogeneous ethnic culture that had traditionally occupied the eastern portions of the Ecuadorian and Colombian Amazon. Their way of life was first threatened by an onslaught of oil-hungry explorers in the 1960s. The city of Lago Agrio, also established by Texaco in this decade, brought in colonists from various parts of the country to occupy areas in and around traditional Cofan territories [16]. This invasion aroused fears of extinction, and the Cofans were forced to organize themselves in communal fashion to build a strong representative organization, today called FEINCE (Federacion Indigena de la Nacionalidad Cofan del Ecuador). Community leaders began counter-mapping exercises [56] of their lands in order to petition assistance from national and transnational organizations. Their efforts proved effective in 1974 when they were able to attain their first land title which recognized their ancestral occupation. Today, they hold secured rights and management agreements for approximately one million hectares of their ancestral territory (Figure 1) [16]. Still threatened by heavy development and colonization in areas directly adjacent to their lands however, the Cofans have been forced to continuously create strategic conservation activities to protect their islands of primary forest along with their culture. Today they have developed their own system of park guards to parole the borders of their lands and have negotiated co-management and cooperative agreements with the ministry of the Environment to also manage lands within protected reserves [16].

Figure 1. Territory managed by the Cofan Indian nation in Ecuador (in gray). Adapted from [57].
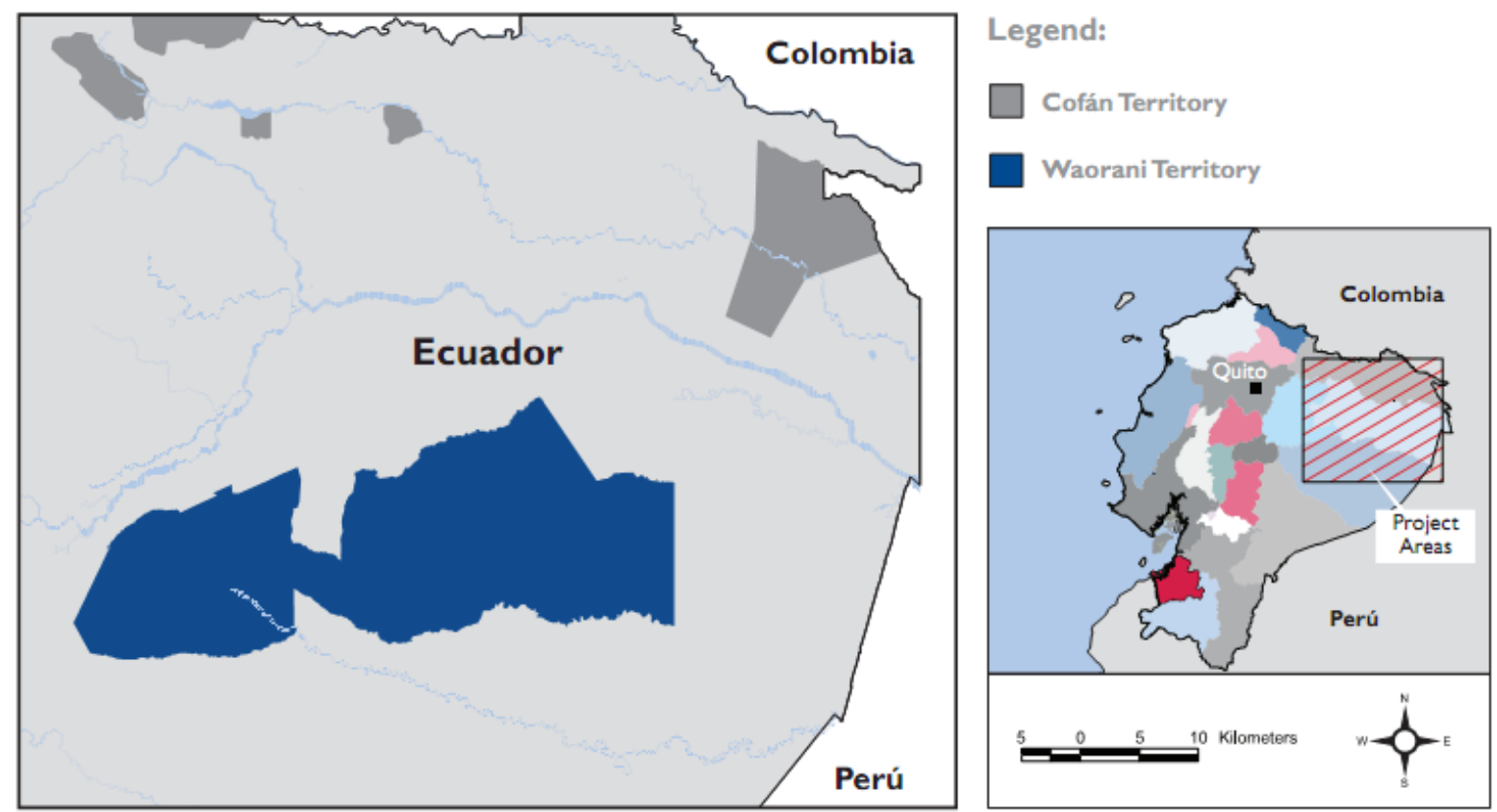
Such measures have brought deforestation within Cofan territories down to a historic minimum. Despite their achievements however, they must now concentrate their efforts on gaining the financial sustainability required for them to continue their conservation practices [16]. Eco-tourism has been a logical choice in their search, and has brought moderate success; but by no means has this endeavor made the Cofans' conservation efforts financially solvent. As such, they have begun to explore other avenues of support, including carbon markets. Even by their own admittance however, REDD+ is a particularly hard model for them to develop [16]. The trouble here once again lies with the additionality most of these projects seek. The creation of baselines or 'business as usual' scenarios is extremely difficult as foreign incursions into their forests come mainly in the form of small, illegal logging or artisanal mining operations [16]. These incursions are typically sporadic in nature, and become difficult to detect, predict, and prevent. This is perhaps why the Cofans have chosen to sign on to the government's Socio-Bosque program, since it currently has no link to carbon markets, emissions reductions, or to additionality clauses in its contracts. Despite this, the incentives offered by the program are still relatively low, and the Cofans are forced to continue their pursuit of financial support to guard their forests through other means.

On the other side of the coin are the Awa and Waorani communities, which seem to have continuous problems with their clash with western civilization. These indigenous groups still struggle to organize themselves well enough to consolidate their territories and to construct effective political representative institutions. As such, they are currently incapable of carrying out REDD+ projects.

\subsection{The Waorani}

The Waorani are a very interesting case-study in this respect. Their particular culture, history, and tumultuous contact with western civilization have not allowed them to collectively organize as effectively as the Cofan. Known as fierce warriors, their traditional use of violence against each other and towards foreign incursions onto their territory has gained them the dubious distinction of being called 'aucas', a local term meaning savages. Though they may have originally numbered in the tens of thousands, today their numbers have been reduced to just two thousand and their formally recognized territory is only a third of what their ancestral possession used to be [14]. Like the Cofans, their history in the last three decades has been one of encroachment on their lands by Christian missionaries, oil companies, and usurpers, both Mestizo colonists and other indigenous groups alike.

Their battle to preserve some vestige of autonomy involved creating their own organization named ONHAE in 1990. This institution was later renamed NAWE (Nacionalidad Waorani del Ecuador). Unlike FEINCE however, and contrary to their credo to resist the powerful forces that facilitate encroachment of their land, this organization has been showered with dubious offerings by the State and representatives of the extractive industries. In various ways, they have been coerced to sign agreements with state officials and oil companies in blatant contradiction to their public statements and organizational positions [14]. As a result, NAWE remains a relatively weak association, still working to unite Waorani communities while competing with and trying to resist powerful outside influences. Today six oil concession blocks overlap their territory and a vast block of land historically held as ancestral land is now the Yasuni National Park, under the jurisdiction of the government (Figure 2). Though they were granted a set of legal titles to over 600,000 hectares of their territory in 1990, the 
government still claims access rights to the subsoil resources, and the conditions of the agreement forbid them to obstruct oil development and receive any royalties stemming from it [14].

Figure 2. Territory managed by the Waorani Indian nation in Ecuador (in blue). Adapted from [57].
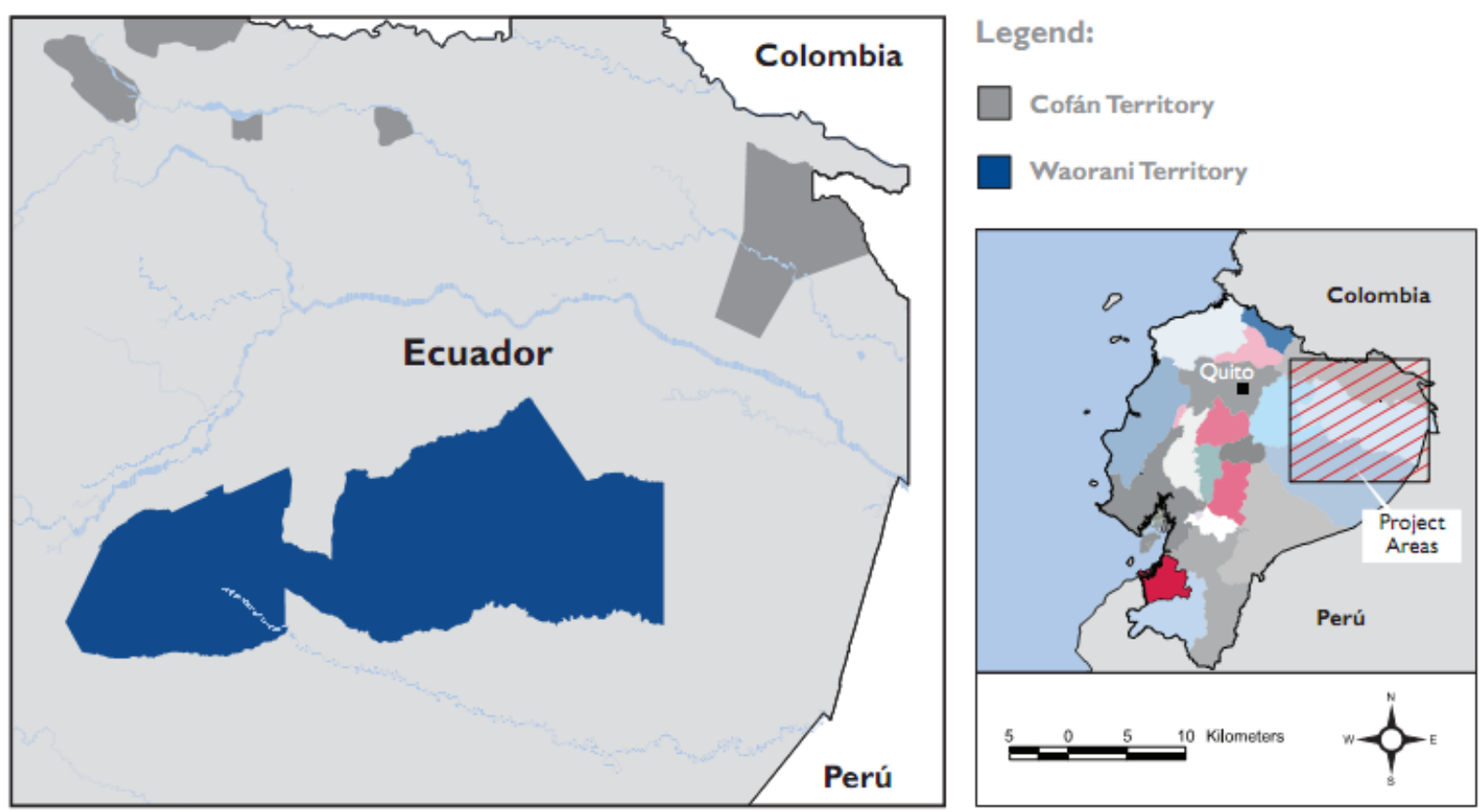

Such circumstances make REDD+ a farfetched possibility for the Waorani. Retaining rights to their land through large global titles also inhibits the potential of separate communities from joining such project schemes. In many cases, borders between neighboring Waorani communities are still un-demarcated and fluid. At the very least, monitoring and verification of projects would be very difficult under such circumstances. In a worst case scenario, REDD+ could have the potential to create serious inter-community conflicts that could even ignite violence among clans that have historically been antagonistic. What is more, many Waorani communities live within the Yasuni National Park while others reside on lands that have been given to foreign oil companies as concessions. NAWE, which is still not recognized as a viable, representative organization by many Waorani [14], is thus also still incapable of designing credible and fair benefit distribution systems.

Even Socio-Bosque is currently not an option for the Waorani. The community of Kiwaro has recently expressed interest in joining. In preparation, they have mapped and zoned out areas within their community that they would wish to incorporate into the program [14]. While they have overcome the obstacle mentioned earlier by clearly marking their boundaries with neighboring communities, benefit distribution under Socio-Bosque rules creates yet another problem. The program offers an incentive of $\$ 30$ dollars per hectare to communities who can present legal titles to their land. But, as the amount of hectares involved in the project begin to grow, the incentives draw down. Socio Bosque offers $\$ 30$ dollars only for the first 50 hectares that are inscribed. It then offers $\$ 20$ for each of the next 50 hectares, ten dollars for the following 400 hectares, five dollars for the next 4,500 hectares, and finally $\$ 0.50$ for those hectares of land above this amount. If benefits are distributed on an individual community basis, and Kiwaro is allowed to join first, other Waorani communities who wish to join the 
program at a later date would receive much less because of the larger, global land titles. Once again, this could very well cause more internal problems within the territory. As a result, Waorani leaders believe that they would be better off dedicating their efforts to the consolidation of their territory through a reinvigorated NAWE that can act as the voice for the entire Waorani tribal-nation before even beginning to consider REDD+ [14].

\subsection{The Awa}

The Awa people of northwestern Ecuador share similar challenges. They are an ancestral indigenous group that resides in the northwestern portion of the country with a considerable portion of their population residing on the Colombian side of the border. They have a unique culture and language and were not formally recognized as an ethnic group by the government until the 1970s [4]. The 22 legally established communities on the Ecuadorian side are represented by FCAE (Federation of Awa communities in Ecuador). FCAE has been actively seeking legal tenure of Awa land from the government and today holds 115,336 hectares of community territory under various versions of deeds in the northern provinces of Esmeraldas, Carchi and Imbabura (Figure 3) [4]. Like the Waorani, their forests are continuously threatened by illegal logging and mining ventures. They also suffer threats from large oil palm plantations, have numerous land disputes with bordering Afro-Ecuadorian communities in the west, and have even been victims of incursions and violence by rebel guerilla groups near the Colombian border [4].

Figure 3. Territory managed by the Awa Indian nation within Ecuador. Adapted from [57].
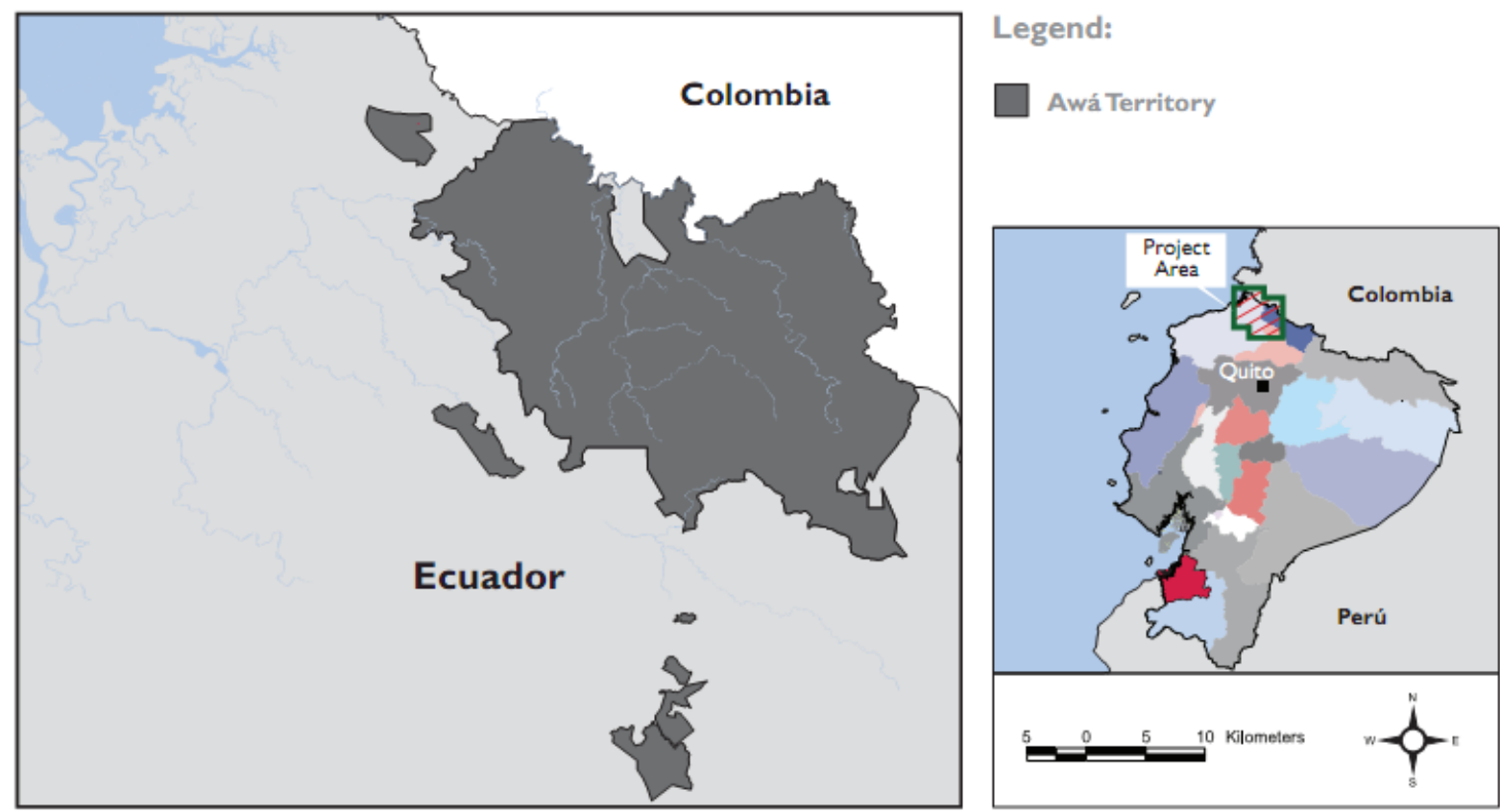

Their main priorities are also the effective protection and consolidation of their territory, and as a result, are also not considering REDD+ or Socio-Bosque cooperation until this is accomplished. Since little help has come from the state to protect their lands or to improve their cultural or economic well-being, their opposition to REDD+ is probably more political than anything. However, their 
arguments further exemplify the apparently contradictory policies of the government and reveal other shortcomings of the Socio-Bosque program.

Under Socio-Bosque, communities are required to sign an agreement stating that they will conserve their forested land for a period of twenty years. However, no clause exists stating that the government will keep their end of the bargain. By their own admittance, Socio-Bosque projects promoters say that they can't guarantee the state will not override their end of the agreements with communities in the future [2]. The Awa feel it's ludicrous that if they enter such a contract the state may still enter their lands to conduct more resource extraction activities. What is more, since they still suffer from constant incursions by outsiders, the Awa are afraid that if forest-cover loss increases with each incursion, that they would be inclined to break such agreements. Under current Socio-Bosque rules, not only would financial benefits be discontinued in such cases, but some communities may be required to give back a certain percentage of the money that they had been receiving [2]. Such provisions make many Awas fearful that entering Socio-Bosque at this moment might bring them more harm than good [4].

Adding fuel to the fire is the particular disdain that Awa leaders currently hold towards government led efforts for development and Western society views of the environment. Furthermore, this disdain supplements the notion that a large portion of opposition to REDD+ is ideological. As an Awa community leader put it,

"We hate the fact that now our forests are being viewed by others as financial commodities. The notion that outsiders can place a price on our resources is ridiculous. Our forests and our lands mean so much more to us. Without them we are nothing. Outsiders simply don't understand this.

\section{Anonymous Awa Community Leader [4]}

\section{Conclusions and Moving Forward}

Ricketts et al. [58] note how incorporating indigenous lands and protected areas into a national REDD+ strategy can greatly increase the chances of reducing country wide emissions. With $60 \%$ of the country's remaining forests under such a classification, it is clear that the Ecuadorian government simply cannot afford to ignore such a recommendation. However, the task at hand is an extremely difficult one.

For one, the state needs to repair a broken relationship with the leadership of the indigenous movement; a task made that much more difficult due to two profoundly different and diverging notions of how to interpret the articles of the new constitution and what type of role the environment should play in the development of the nation. Unfortunately, such a problem moves beyond politics, and will not be solved once the indigenous movements' leadership is replaced or when Rafael Correa leaves office. Ecuador's reliance on an extractive economy cannot be overturned overnight. Even though both parties may wish to see the country's economy move from one of extraction to one of services, it is apparent that both also have vastly different timelines for which they would like to see this occur. Indigenous leaders would like to see the immediate withdrawal of all extractive transnational companies from their territories, while government leaders know they must continue to rely on those resources if the country's economy is to remain afloat. Payments for environmental services, such as 
REDD+, may provide some of the most credible circumstances under which such a transition may begin to occur, yet such a strategy also comes with its own set of obstacles.

Whether it is politics or a lack of coordination on the part of authorities to make the most basic of information about REDD+ available to communities, the fact remains that indigenous opposition to the initiative remains strong within Ecuador. What is more, just as can be witnessed at the global stage, it is apparent that this opposition is also fueled by strong ideological differences. The commodification of nature, and the possible use of international markets and neoliberal mechanisms in a future REDD+ scheme, are the most prominent points of contention for indigenous leaders. Considering themselves and their territories as primary victims of such ideals in the past, they not only view these new types of projects as a continuation of the type of policies that have impeded their arduous quest for sovereignty, but even as a harm that may bring about more deforestation and climate change. Despite such dire circumstances, however, there are some apparent signs of encouragement and possible paths to reconciliation.

Representations of indigenous views on REDD+ and other conservation and development topics can oftentimes be oversimplified. In this particular case, it is evident that the indigenous stand on REDD+ and other such projects is by no means monolithic. While opposition remains strong amongst top level indigenous representatives and leaders, different perspectives and voices were found at the individual tribal-nation and village levels. While some communities share the sentiments of CONAIE and other opposition groups, others are beginning to perceive that they may have something to gain from REDD+. Communities, such as the Waorani and Cofan, are constantly seeking ways with which to safeguard their resources and territories, and are actively considering carbon markets as a possibility. However, the organizational capacity of different indigenous communities presents yet another hurdle that must be overcome if REDD+ is ever to be carried out on their lands. Future projects will have to accommodate to the particular conditions of different indigenous communities, while at the same time recognize that they will require differing modes of preparation and implementation, and will also produce different types of outcomes.

On the one hand, there are those communities whose particular circumstances and recent clashes with western civilization still force them to concentrate their efforts on the effective consolidation and protection of their territories as well as the creation of viable political systems of internal government. The prospects of carrying out REDD+ projects on their lands seems non-existent without these pre-conditions. On the other hand, efforts must be made to include those communities that have reached such circumstances but who, as a result, have already brought deforestation within their territories to a minimum, and as such may not provide the additionality and rapid reductions in emissions REDD+ investors seek. Without the financial and institutional support that may allow them to continue safeguarding their forests, there is the risk that such lands may also come under attack once more.

Due to these circumstances, the Socio-Bosque program plays a critical role in this respect. It doesn't deal directly with the carbon emissions trade process and holds no additionality clauses within its contracts. It represents a credible system by which indigenous communities could be incorporated into a national strategy to reduce deforestation. With its direct distribution of benefits to member communities, it also offers a model by which future REDD+ projects may avoid the traditional disbursement of funds in development projects. Perhaps most importantly however, it creates an 
avenue to compensate those communities which have been safeguarding their forests this entire time, and provides the financial support needed to allow them to continue doing so. Although some aspects of its current policy framework may need to be adjusted, it also represents a logical starting place to reconcile REDD+'s objectives with the indigenous sector.

Though opposition to REDD+ remains strong within Ecuador, there is no reason why the government could not use this push for a national strategy as appeasement for the country's indigenous communities. A number of observers have proposed that the design of REDD+ projects could and should be used to advance the rights of forest-dependant poor communities by increasing their tenure security and creating direct livelihood benefits [41,43,59]. However, the Ecuadorian government would be well advised to proceed with the utmost caution and respect in this arena. A consultation process to implement article 74 of the new constitution must be sponsored. Legal frameworks for compensating environmental services projects and to clarify jurisdiction over carbon rights must include as much participation from the indigenous sector as possible. Safeguards for their sovereignty and customs, along with direct and equitable benefit distribution models, will be paramount. The indigenous communities will not buy into such schemes if they don't perceive concrete and tangible rewards for their contributions, as well as guarantees for the protection of their territories and autonomy.

For indigenous communities to be able to participate in REDD+, it remains clear that they will have to reach a distinctive level of institutional capacity in order for these projects to be effective and bring more benefit than harm. National government authorities could aid these communities in order to help them consolidate their territories, resolve ongoing land disputes, and aid in the negotiation of agreements between neighboring communities. Furthermore, assistance should be given to these groups in order to establish modern and viable political approaches for self-representation, which would in turn also help facilitate the creation of appropriate benefit distribution mechanisms in the future. Government assistance in these crucial areas would not only help prepare indigenous communities to be able to participate in REDD+, but it would also serve as the first logical step in trying to repair a broken relationship that has made progress so difficult in recent times.

Given a lingering lack of confidence and trust on the part of some indigenous groups towards government officials and project promoters, indigenous to indigenous exchanges are perhaps a most promising approach with which to move forward. Using the positive and relatively trouble-free experiences with Socio-Bosque thus far as examples, the indigenous themselves should be the ones to convey this information to other indigenous groups. Such a strategy could minimize the distrust that has been generated by the political break between Correa's administration and the larger indigenous movement. What is more, such a strategy could also foster 'positive leakage', whereby, perceiving how their counterparts are reaping benefits while not suffering threats to their sovereignty and traditional ways of living, other indigenous communities may begin to consider Socio Bosque or other REDD+ projects as possible options.

The enthusiasm brought on by REDD+ on a worldwide scale may very well put into motion the necessary conditions under which the age old problem of deforestation in the tropics and the contemporary mission to reduce carbon emissions may be plausibly conjoined and attacked. What is more, it offers an alternative to the traditional law enforcement and exclusionary policies of the past which have done little, if anything, to reduce deforestation. However, just as Ecuador must devise a 
strategy to 'tweak' the typical REDD+ model being produced in order to incorporate indigenous communities under a national strategy, so too should the global carbon policy community begin to realize that REDD+ will not be a grandiose, "one-size-fits-all” piece of policy architecture. REDD+ projects should only be part of the strategy; and the negative and positive signs REDD+ has provided thus far should be evaluated and then addressed.

Taking the indigenous view of the world as an example, acknowledgment that other instinctive interconnections exist between social and natural systems is indispensable. Conventional constructs and policy predispositions should be considered as well as challenged. But, if indigenous communities do decide to enter into REDD+ projects, it must not be forgotten that they, once more, enter a realm of modernity where new money and institutional agreements can once again alter their natural environments and ways of life in ways never seen before. Further research and considerations of what these changes might entail will be crucial in the years to come. Ironically, foremost to a strategy that includes indigenous communities under a REDD+ policy framework may be one that consents to complete freedom on the part of the indigenous to simply say no to REDD+ if they so choose.

\section{Acknowledgements}

This study was made possible by the generous donation of the Compton Foundation and the support of Michael Dove, Susan Clark, Lloyd Irland, and Amity Doolittle at the Yale School of Forestry and Environmental Studies. A special thanks to Anthony Stocks, Andrew Noss, Lourdes Barragan, Pablo Landivar, Randy Borman, Karen Podvin, and Andrea Garzon for their guidance and support within Ecuador. Lastly, a special thank you to Victoria Clavijo, Alan Reed, and Angela Reed for their periodic edits, advice, and unconditional love and support throughout this process.

\section{References}

1. United Nations. REDD Programme. Available online: http://www.un-redd.org/AboutREDD/ tabid/582/Default.aspx (accessed on 6 January 2011).

2. Podvin, K. Socio-Bosque Program, Quito, Ecuador. Personal communication, July 2010.

3. Anonymous representative. Fundacion Pachamama, Quito, Ecuador. Personal communication, July 2010.

4. Anonymous Awa leader. FCAE (Federacion de Centros Awa del Ecuador), Ibarra, Ecuador. Personal communication, July 2010.

5. Anonymous representative. Fundacion Accion Ecologica, Quito, Ecuador. Personal communication, July 2010.

6. Confederacion de Nacionalidades Indigenas del Ecuador (CONAIE). Available online: http://www.conaie.org/component/content/article/2-notis2/328--los-grupos-de-pueblos-indigenasanuncian-serias-preocupaciones-por-el-posible-resultado-de-cancun (accessed on 10 January 2011).

7. Palacios, W. Potencial etnobotánico de los territorios indígenas en el Ecuador. Revista Bosques Latitud Cero. 2005, 2, 19-25.

8. Phelps, J.; Guerrero, M.C.; Dalabajan, D.A.; Young, B.; Webb. E.L. What makes a 'REDD+' country? Global Environ. Change 2010, 20, 322-332. 
9. Barragan, L. CEPLAES, Quito, Ecuador. Personal communication, June 2010.

10. Griffiths, T. Seeing 'REDD+' Forests, Climate Change Mitigation and the Rights of Indigenous Peoples and Local Communities; Updated Report; Forests and Peoples Programme: London, UK, 2009; p. 63.

11. Tauli-Corpuz, V.; UNPFII. Statement on the Announcement of the World Bank Forest Carbon Partnership Facility; United Nations Permanent Forum on Indigenous Issues: Bali, Indonesia, 2007.

12. REDD Monitor. Available online: http://www.redd-monitor.org/2010/09/30/evo-morales-natureforests-and-indigenous-peoples-are-not-for-sale/ (accessed on 6 October 2010).

13. Sawyer, Suzana. Crude Chronicles; Duke University Press: Durham, NC, USA, 2004.

14. Anonymous Waorani representative. NAWE (Nacionalidad Waorani del Ecuador), Puyo, Ecuador. Personal communication, July 2010.

15. Anonymous Waorani technician. NAWE (Nacionalidad Waorani del Ecuador), Puyo, Ecuador. Personal communication, July 2010.

16. Borman, R. FEINCE (Federacion Indigena de la Nacionalidad Cofan del Ecuador) Quito, Ecuador. Personal communication, June 2010.

17. Plan Nacional para el Buen Vivir 2009-2013. SENPLADES 2009, Available online: http://plan.senplades.gov.ec/ (accessed on 16 June 2010).

18. Mast, R.B.; Mittermeier, C.G.; Mittermeier, R.A.; Rodríguez-Mahecha, J.V.; Hemphill, A.H. Megadiversity: Earth's Biologically Wealthiest Nations; Mittermeier, R.A., Robles Gil, P., Mittermeier, C.G., Eds.; CEMEX: Monterrey, Mexico, 1997; pp. 314-324.

19. Ministerio del Ambiente del Ecuador. Available online: http://www.ambiente.gob.ec/ sites/default/files/users/mponce/tasadedeforestacion.pdf (accessed on 20 April 2010).

20. Sistema Integrado de Indicadores Sociales del Ecuador (SIISE 4.5), 2001. Available online: http://www.siise.gov.ec/ (accessed on 15 May 2010).

21. Banco Central del Ecuador: Evolucion de la Economia Ecuatoriana, Julio 2010. Available online: http://www.bce.fin.ec/ (accessed on 16 August 2010).

22. Lascano, M. Valoración de la Contribución Forestal a la Economía Nacional: Caso de Ecuador. In the Amazon Cooperation Treaty Organization and FAO Forestry Commission Report; ACTO: Puyo, Ecuador, 2008.

23. Parker, C.; Mitchell A.; Trivedi M.; Mardas, N. The Little REDD+ Book: A Guide to Governmental and Non-Governmental Proposals for Reducing Emissions from Deforestation and Degradation; Global Canopy Project: Oxford, UK, 2008.

24. FAO. State of the World's Forests; Food and Drug Administration: Rome, Italy, 2007.

25. Steward, R.; Gibson, D. Environmental and economic development consequences of forest and agricultural sector policies in Latin America: A synthesis of case studies of Costa Rica, Ecuador and Bolivia. In Readings of the Workshop on Government Policy Reform for Forestry Conservation and Development in Latin America, Washington, DC, USA, 15 April 1994.

26. World Resource Institute. Available online: http://earthtrends.wri.org/pdf_library/ country_profiles/bio_cou_218.pdf (accessed on 17 July 2010).

27. Anonymous correspondent. Ministerio del Ambiente, Quito, Ecuador. Personal communication, June 2010. 
28. Indigenous Peoples, Poverty and Human Development in Latin America 1994-2004; Hall, G., Patrinos, H., Eds.; World Bank: Washington, DC, USA, 2005.

29. Becker, M. Indians and Leftists in the Making of Ecuador's Modern Indigenous Movements. Duke University Press: Durham, NC, USA, 2008.

30. Becker, M. Pachakutik and Indigenous Political Party Politics in Ecuador. In Latin American Social Movements in the Twenty-First Century: Resistance, Power, and Democracy; Stahler-Sholk, R., Vanden, H.E., Kuecker, G., Eds.; Rowman and Littlefield: Lanham, MD, USA, 2008; pp. 165-180.

31. van Cott, D. Broadening Democracy: Latin America's indigenous peoples movements. Curr. Hist. 2004, 103, 80-85.

32. Li, T. Articulating indigenous identity in Indonesia: Resource politics and the tribal slot. Comp. Stud. Soc. Hist. 2000, 42, 149-179.

33. Perreault, T. Developing identities: indigenous mobilization, rural livelihoods, and resource access in Ecuadorian Amazonia. ECUMENE, Sage Publications 2001, 8, 381-413.

34. Dosh, P. Correa vs Social Movements: Showdown in Ecuador; NACLA Report on the Americas; North American Congress on Latin America: New York, NY, USA, 2009; Volume 42, pp. 21-40.

35. Gudynas, E. La Ecologia politica del giro biocentrico en la nueva Constitutcion del Ecuador. Revista de estudios sociales 2007, 32, 34-46.

36. The News Library. Speech by Rafael Correa: 26 July 2008. Available online: http://rafael-correa-news.newslib.com/2009053123. (accessed on 30 May 2010).

37. Constitucion de la Republica del Ecuador. Available online: http://www.asambleanacional.gov.ec/ documentos/constitucion_de_bolsillo.pdf (accessed on 3 March 2010).

38. President, indigenous groups at odds over fatal protest in Ecuador (2 October 2009). Available online: http://edition.cnn.com/2009 (accessed on 30 May 2010).

39. Knoke, T.; Calvas, B.; Aguirre, N.; Roman-Cuesta, R.M.; Gunter, S.; Stimm, B.; Weber, M.; Mosandl, R. Can tropical farmers reconcile subsistence needs with forest conservation? Front. Ecol. Environ. 2009, 7, 548-554.

40. Indigenous Environmental Network. Available online: http://www.ienearth.org/ carbontrading1.html (accessed on 18 July 2010).

41. Cotula, L.; Mayers, J. Tenure in REDD—Start-Point or Afterthought? Natural Resource Issues No. 15; International Institute for Environment and Development: London, UK, 2009.

42. Czebiniak, R.P.; Breitkopf, S. Greenpeace letter of concern to K. Sierra, Vice-President of Sustainable Development at the World Bank, 2007.

43. Sunderlin, W.D.; Angelsen, A.; Roberts, T. Rights: An essential precondition for effectiveness, efficiency and equity in REDD+. Presentation at Forest Day: Shaping the Global Agenda for Forests and Climate Change, Ponzan, Poland, 6 December 2008.

44. Phelps, J.; Webb, E.L.; Agrawal, A. Does REDD++ threaten to recentralize forest governance? Science 2010, 328, 312-313.

45. Dove, M.R. A revisionist view of tropical deforestation and development. Environ. Conserv. 1993, 20, 17.

46. Hirtz, F. It takes modern means to be traditional: On recognizing indigenous cultural communities in the Philippines. Develop. Change 2003, 34, 887-914. 
47. Ministerio del Ambiente del Ecuador. Available online: http://www.ambiente.gob.ec/?q=node/57 (accessed on 23 May 2010).

48. Conservation International. Available online: http://www.conservation.org/FMG/Articles/Pages/ grand_plan_ecuador_and_forest_partners.aspx (accessed 17 May 2010).

49. Anonymous Awa villager. FCAE (Federacion de Centros Awa del Ecuador), Ibarra, Ecuador. Personal communication, July 2010.

50. Anonymous Chachi conference attendee. Tena, Ecuador. Personal communication, July 2010.

51. Pimpert, M.P.; Pretty, J.N. Parks, People and Professionals: Putting "Participation" into Protected Area Management; United Nations Research Institutute for Social Development: Geneva, Switzerland, February 1995.

52. Heller, J. Catch-22: A Novel; Simon \& Schuster Classics: New York, NY, USA, 1999.

53. Becker, M. Grassroots to grassroots: why forest preservation was rapid at Loma Alta, Ecuador. World Dev. 2003, 31,163.

54. Kaimowitz, D. The prospects for Reduced Emissions from Deforestation and Degradation (REDD) in Mesoamerica. Int. For. Rev. 2008, 10, 485-495.

55. Ascher, W. Communities and Sustainable Forestry in Developing Countries; Institute for Contemporary Studies (ICS): San Francisco, CA, USA, 1995.

56. Peluso, N.L. Whose woods are these? Counter-mapping forest territories in Kalimantan, Indonesia. Antipode 1995, 27, 383-406.

57. United States Agency for International Development. Available online: http://pdf.usaid.gov/pdf_docs/PNADK832.pdf (accessed 30 March 2011). Used with permission from USAID.

58. Ricketts, T.H.; Soare-Filho, B.; Fonseca, G.; Nepstad, D.; Pfaff, A.; Petsonk, A.; Anderson A.; Boucher, B.; Cattaneo, A.; Conte, M.; et al. Indigenous lands, protected areas, and slowing climate change. PLoS Biology 2010, 8, e1000331.

59. Brown, D.; Seymour, F.; Peskett, L. How do we achieve REDD+ co-benefits and avoid doing harm? In Moving ahead with REDD+: Issues, Options and Implications; Angelsen, A., Ed.; CIFOR: Bogor, Indonesia, 2008; pp. 107-118.

(C) 2011 by the authors; licensee MDPI, Basel, Switzerland. This article is an open access article distributed under the terms and conditions of the Creative Commons Attribution license (http://creativecommons.org/licenses/by/3.0/). 